\title{
Therapeutic Efficacies of Self-Formulated Anti-Oxidant Trace Minerals Formulation in Bovine Mastitis
}

\author{
A. Muhee $^{1 *}$, H. U. Malik ${ }^{1}$, I. Asharaf ${ }^{1}$, O. S. Shah ${ }^{1}$, A. Jan ${ }^{1}$, Muheet ${ }^{1}$, \\ W. Rather ${ }^{1}$ and Showkeen Muzamil ${ }^{2}$ \\ ${ }^{1}$ Department of Veterinary Medicine ethics and jurisprudence, F.V.Sc \& A.H, SKUAST-K, \\ Srinagar- 192301, Jammu and Kashmir, India \\ ${ }^{2}$ Molecular Biology Lab, Division of Veterinary Biochemistry, Faculty of Veterinary Sciences \& \\ Animal Husbandry, Sheri Kashmir University of Agricultural Science \& Technology-Kashmir \\ (SKUAST-K), Srinagar, J\&K-190006, India \\ *Corresponding author
}

A B S T R A C T

\begin{tabular}{|l|}
\hline Ke y w or d s \\
$\begin{array}{l}\text { Therapeutic efficacies, } \\
\text { self-formulated anti- } \\
\text { oxidant }\end{array}$ \\
\hline Article Info \\
\hline $\begin{array}{l}\text { Accepted: } \\
\text { 28 June } 2017 \\
\text { Available Online: } \\
\text { 10 July } 2017\end{array}$ \\
\hline
\end{tabular}

The study was undertaken on clinical cases of bovine mastitis presented to Teaching Veterinary Clinical Complex (TVCC), F.V.Sc \& A.H, SKUAST-K and adjoining areas during the course of study August 2014-May 2016. For therapeutic trials, the clinical cases of mastitis were divided into two groups. In Animals of Group I therapeutic regimen I was used conducted and included 15 clinical cases of mastitis, in Group II animal's therapeutic regimen II was used and included 12 clinical cases of mastitis. The animals of group II were given self-formulated anti-oxidant trace mineral mixture. Group II animals were not given any anti-oxidant trace mineral mixture. The requirements of trace minerals like $\mathrm{Cu}$, $\mathrm{Zn}, \mathrm{Mn}$ and Se are increased in mastitis as evidenced by their decreased levels in clinical mastitis and improved clinical response on their supplementation. Anti-oxidant trace minerals like $\mathrm{Cu}, \mathrm{Zn}, \mathrm{Mn}$ and Se significantly reduce oxidative stress and augment clinical recovery and may play a significant role in treatment of mastitis in lactating animals.

\section{Introduction}

Mastitis is a parenchymal inflammation of the mammary gland, which is caused by microorganisms, usually bacteria that invade the udder, multiply and produce toxins which are harmful to the mammary gland (Sharma et al., 2006). Mastitis could induce increased formation of free radicals in milk leading to oxidative stress (Gu et al., 2009). Substantial amounts of free radicals are produced during an inflammatory response such as that which occurs when the mammary gland becomes infected. Antioxidant supplementation could decrease the duration; incidence and severity of clinical mastitis as the formation of increased free radicals during mastitis are mostly associated with decreased antioxidant defence. Trace elements with anti-oxidant function include copper, zinc, manganese, iron and selenium which act as co-factors for anti-oxidant enzymes superoxide dismutase, catalase and glutathione peroxidase which are directly or indirectly involved in quenching or 
neutralising the excess free radicals generated due to oxidative stress. The present study was thus undertaken to evaluate the therapeutic efficacy of self-formulated anti-oxidant trace mineral formulation in bovine mastitis.

\section{Materials and Methods}

A total of 39 multiparous cows in the age group of 4-8 years with BCS 3.0 were included for the study. The study was undertaken on clinical cases of bovine mastitis presented to Teaching Veterinary Clinical Complex (TVCC), F.V.Sc \& A.H, SKUAST-K and local animal husbandry dispensaries in Ganderbal, Manasbal, Shuhama, Gulab bagh and Shalimar areas during the course of study August 2014-May 2016. 27 animals were found to be affected with clinical mastitis and 12 apparently healthy lactating animals served as control group. For therapeutic trials, the clinical cases of mastitis were divided into two groups. In Animals of Group I therapeutic regimen I was used conducted and included 15 clinical cases of mastitis, in Group II animals therapeutic regimen II was used and included 12 clinical cases of mastitis. The animals of group II were given self-formulated anti-oxidant trace mineral mixture at therapeutic doses as recommended by NRC, 2001. Group II animals were not given any anti-oxidant trace mineral mixture.

Both the groups of animals were given antibiotic enrofloxacin at the dose rate of $6.6 \mathrm{mg} / \mathrm{kg}$ per animal twice daily for 5 days. The therapeutic trial design for cows with clinical mastitis is provided in Table 1.Trace minerals like copper $(\mathrm{Cu})$, zinc $(\mathrm{Zn})$, manganese $(\mathrm{Mn})$ and selenium(Se) were estimated from the plasma of normal as well as mastitic animals on day 0 and day 10 of treatment after acid digestion of samples. The samples were analysed at Kashmir University, Hazratbal in the Department of University Scientific Instrumentation Centre (USIC) using Polarised Zeeman Atomic Absorption Spectrophotometer (Z-2300, Hitachi).

\section{Results and Discussion}

The therapeutic efficacy of two treatment regimens with mean days of recovery in both the groups of animals is depicted in Table 2. In group I, 15 clinical cases of mastitis were given self-formulated mineral mixture once daily for 7 days. In this group of animals, eleven animals recovered within mean of $4 \pm 0.5$ days as was evidenced by clinical recovery (CMT negative) and return of milk SCC and milk chemistry parameters to normal. The percent recovery was $73.33 \%$.

The rest of the animals (four) did not recover by the treatment regimen I provided to these animals as evidenced by CMT positive scores, constantly higher milk SCC values and abnormal milk chemistry. Group II constituted 12 clinical cases of mastitis and were not given any mineral mixture. In group II, twelve animals were treated out of which eight animals recovered completely within mean of $4.5 \pm 0.8$ days as evidenced by clinical recovery (CMT negative) and return of milk SCC and milk biochemical parameters to normal, The per cent recovery was $66.66 \%$.The rest of the animals (four) did not recover by the treatment regimen II provided to these animals as evidenced by CMT positive scores, constantly higher milk SCC values and abnormal milk chemistry. The mean values of copper and manganese in the mastitic group were statistically significant from the mean values of copper in the normal control group $(\mathrm{p}<0.05 \%)$. The mean values for $\mathrm{Cu}(\mu \mathrm{mol} / \mathrm{L})$ and $\mathrm{Mn}(\mu \mathrm{mol} / \mathrm{L})$ for group I animals in the mastitic group receiving therapeutic regimen $I$ on day 0 and day 10 in group I animals differed significantly from each other $(\mathrm{p}<0.05)$ while no significant difference was observed in animals of group II (Table 3). 
Table.1 Therapeutic trial design for cows with clinical mastitis

\begin{tabular}{|c|c|c|c|c|c|c|}
\hline Group & $\begin{array}{l}\text { No. of animals } \\
\text { treated }\end{array}$ & Treatment & Dosage & Route & Frequency & $\begin{array}{l}\text { Duration of } \\
\text { treatment }\end{array}$ \\
\hline \multirow{2}{*}{$\begin{array}{l}\text { Group I } \\
\text { (Therapeutic } \\
\text { regime I) }\end{array}$} & \multirow[t]{2}{*}{15} & \multirow{2}{*}{$\begin{array}{l}\text { Inj. Enrofloxacin and } \\
\text { Anti-oxidant trace } \\
\text { mineral mixture }\end{array}$} & $6.6 \mathrm{mg} / \mathrm{Kg}$ & $\mathrm{I} / \mathrm{M}$ & BID & \multirow[t]{2}{*}{5 days } \\
\hline & & & $5.005 \mathrm{gms}$ & Oral & OD & \\
\hline $\begin{array}{l}\text { Group II } \\
\text { (Therapeutic } \\
\text { regime II) }\end{array}$ & 12 & Inj. Enrofloxacin & $6.6 \mathrm{mg} / \mathrm{Kg}$ & $\mathrm{I} / \mathrm{M}$ & BID & 5 days \\
\hline
\end{tabular}

Table.2 Therapeutic efficacy of treatment regimes in animals with clinical mastitis

\begin{tabular}{|l|l|l|}
\hline & Group II & Group III \\
\hline Animals treated & 15 & 12 \\
\hline Animals Recovered & 11 & 8 \\
\hline \% Recovery & $73.33 \%$ & $66.66 \%$ \\
\hline Recovery time (Days \pm S.E) & $4 \pm 0.5$ & $4.5 \pm 0.8$ \\
\hline
\end{tabular}

Table.3 Comparison of milk SCC and trace mineral profile between healthy lactating (control group) and mastitic animals

\begin{tabular}{|l|l|l|}
\hline Parameters & Control Group & Mastitic Group \\
\hline $\mathrm{SCC}\left(\times 10^{5} / \mathrm{mL}\right)$ & $2.83 \pm .05^{\mathrm{a}}$ & $9.94 \pm 0.22^{\mathrm{b}}$ \\
\hline $\operatorname{Copper}(\mu \mathrm{mol} / \mathrm{L})$ & $8.25 \pm .07^{\mathrm{a}}$ & $7.01 \pm 0.06^{\mathrm{b}}$ \\
\hline Zinc $(\mu \mathrm{mol} / \mathrm{L})$ & $14.47 \pm .31^{\mathrm{a}}$ & $11.71 \pm 0.16^{\mathrm{b}}$ \\
\hline $\mathrm{Mn}(\mu \mathrm{mol} / \mathrm{L})$ & $3.78 \pm .11^{\mathrm{a}}$ & $2.94 \pm 0.04^{\mathrm{b}}$ \\
\hline $\mathrm{Se}(\mathrm{ng} / \mathrm{mL})$ & $38.47 \pm 1.67^{\mathrm{a}}$ & $31.29 \pm 1.14^{\mathrm{b}}$ \\
\hline
\end{tabular}

Values within a row having superscript $(\mathrm{a}, \mathrm{b}, \mathrm{c})$ with atleast one common alphabet do not differ significantly at $5 \%$ level $(\mathrm{p}<0.05)$ from each other.

Table.4 Effect of therapeutic regimens on trace mineral profile of animals with clinical mastitis

\begin{tabular}{|l|c|c|c|}
\hline \multirow{2}{*}{ Parameters } & Days of treatment & $\begin{array}{l}\text { Group I (Antibiotic + } \\
\text { Antioxidant trace minerals) }\end{array}$ & $\begin{array}{l}\text { Group II } \\
\text { (Antibiotic only) }\end{array}$ \\
\hline Se $(\mathrm{ng} / \mathrm{mL})$ & Day 0 & $29.94 \pm 1.80^{\mathrm{a}}$ & $32.98 \pm 1.16^{\mathrm{a}}$ \\
\cline { 2 - 4 } & Day 10 & $35.39 \pm 1.46^{\mathrm{b}}$ & $31.67 \pm 1.08^{\mathrm{b}}$ \\
\hline \multirow{2}{*}{$\mathrm{Mn}(\mu \mathrm{mol} / \mathrm{L})$} & Day 0 & $2.94 \pm .06^{\mathrm{a}}$ & $2.94 \pm .04^{\mathrm{a}}$ \\
\hline \multirow{2}{*}{ Zinc $(\mu \mathrm{mol} / \mathrm{L})$} & Day 10 & $3.30 \pm .03^{\mathrm{b}}$ & $2.93 \pm .05^{\mathrm{a}}$ \\
\cline { 2 - 4 } & Day 0 & $11.86 \pm .22^{\mathrm{a}}$ & $11.52 \pm .22^{\mathrm{a}}$ \\
\hline \multirow{2}{*}{ Copper $(\mu \mathrm{mol} / \mathrm{L})$} & Day 10 & $13.85 \pm .21^{\mathrm{b}}$ & $11.13 \pm .16^{\mathrm{b}}$ \\
\cline { 2 - 4 } & Day 0 & $6.88 \pm .06^{\mathrm{a}}$ & $7.18 \pm .10^{\mathrm{a}}$ \\
\hline \multirow{2}{*}{$\mathrm{SCC}\left(\times 10^{5} / \mathrm{mL}\right)$} & Day 10 & $7.65 \pm .06^{\mathrm{b}}$ & $7.12 \pm .13^{\mathrm{a}}$ \\
\cline { 2 - 4 } & Day 0 & $9.88 \pm .31^{\mathrm{a}}$ & $10.03 \pm .33^{\mathrm{a}}$ \\
\cline { 2 - 4 } & Day 10 & $3.19 \pm .09^{\mathrm{b}}$ & $4.43 \pm .13^{\mathrm{b}}$ \\
\hline
\end{tabular}

Values within a column having superscript $(\mathrm{a}, \mathrm{b})$ with atleast one common alphabet do not differ significantly at $5 \%$ level $(\mathrm{p}<0.05)$ from each other. 
The present study revealed decreased levels of $\mathrm{Mn}$ in clinical mastitis as compared to normal control group. The mean values of $\mathrm{Zn}$ $(\mu \mathrm{mol} / \mathrm{L})$ and $\mathrm{Se}(\mathrm{ng} / \mathrm{mL})$ for normal healthy control group and the mastitic group (Table 4) differed significantly from each other $(p<0.05)$. The mean values of zinc and selenium on day 0 and day 10 in group I and group II animals differed significantly from each other $(p<0.05)$.

Copper is an important co-factor of superoxide dismutase, an enzyme, which protects cells from the pro-oxidative influence of free radicals (Kleczkowski, 2003). Our findings are in agreement with Kleczkowski, 2008 who also found decreased concentrations of copper in animals with clinical mastitis. Our findings of decreased values of $\mathrm{Mn}$ in clinical mastitis are in agreement with Erskine et al., 1997 and Yang and $\mathrm{Li}$, (2015) who also reported that the plasmatic levels of minerals decrease in clinical mastitis. In our study, the zinc levels in dairy cows with clinical mastitis were low compared with healthy cows. Ibrahim et al., 2016 also found a significant decrease in the values of zinc in cows with clinical mastitis. Low $\mathrm{Zn}$ status leads to low quality milk with high SCC and increased incidence of mastitis (Gaafar et al., 2010). The present study revealed decreased levels of Se in clinical mastitis as compared to normal control group. Our findings of low Se values in clinical mastitis are in agreement with Weiss et al., (1990), Erskine et al., (1987), Grasso et al., (1990) and Kommisrud et al., (2005). Selenium is an essential micronutrient present in tissues throughout the body and is important physiologically because it is an integral component of the enzyme glutathione peroxidase. Weiss et al., (1990), found that high serum Se concentrations are associated with reduced rates of clinical mastitis and low bulk tank milk SCC. Trace elements as copper, iron, zinc, selenium and manganese play important roles in several biochemical processes as they are essential component in the antioxidant enzymes as superoxide dismutase and catalase (Yang and Li, 2015). Our findings of increased recovery rates through the use of anti-oxidant trace mineral supplementation is supported by the findings of Machado et al., (2013) and Sordillo and Mavangira (2014) who also advocated controlling mastitis through appropriate antioxidant supplementation in terms of trace mineral supplementation that could potentially boost the animals health status and performance.

The requirements of trace minerals like $\mathrm{Cu}$, $\mathrm{Zn}, \mathrm{Mn}$ and Se are increased in mastitis as evidenced by their decreased levels in clinical mastitis and improved clinical response on their supplementation. Anti-oxidant trace minerals like $\mathrm{Cu}, \mathrm{Zn}, \mathrm{Mn}$ and Se significantly reduce oxidative stress and augment clinical recovery and may play a significant role in prophylaxis of mastitis in lactating animals.

\section{References}

Erskine, R. J, Bartlett, P. C., Herdt, T. and Gaston, P. 1997.Effects of parenteral administration of vitamin $E$ on health of periparturient dairy cows.Journal of the American Veterinary Medical Association 211:466-469.

Erskine, R.J., Eberhar, R.J. and Hutchinson, L.J. 1987. Blood selenium concentrations and glutathione peroxidase activities in dairy herds with high and low somatic cell counts. Journal of the American Veterinary Medical Association 11: 14171421.

Gaafar, H.M.A., Basiuoni, M.I., Ali, M.F.E., Shitta, A.A. andShamas, A.S.E. 2010. Effect of zinc methionine supplementation on somatic cell count in milk and mastitis in Friesian cows. Archiva Zootechnica13: 36-46.

Grasso, P. J., Scholz, R. W., Erskine,, R. J. and 
Eberhart, R. J. 1990. Phagocytosis, bactericidal activity, and oxidative metabolism of milk neutrophils from dairy cows fed selenium-supplemented and selenium-deficient diets. American Journal of Veterinary Research 51:269274.

Gu, B., Zhu, Y., Zhu, W., Miao, J., Deng, Y.E. and Zou, S. 2009.Retinoid protects rats against neutrophil-induced oxidative stress in acute experimental mastitis. International Immuno pharmacology9 :223-229.

Hoeben, D., Burvenich, C. andHeyneman, R. 1998. Antibiotics commonly used to treat mastitis and respiratory burst of bovine polymorphonuclear leukocytes. Journal of Dairy Science 81: 403-410.

Ibrahim, H.M.M., El-seedy, Y.Y. and Gomaa, N.A. 2016. Cytokine response and oxidative stress status in dairy cows with acute clinical mastitis. Journal of Dairy, Veterinary \& Animal Research 3(1): 2-6.

Kleczkowski M., Klucinski W., Sitarska E., Sikora J., Kasztelan R. 2003.Influence of mineral nutrition on superoxide dismutase activity in blood of cows. Bulletin of the Veterinary Institute in Pulawy 47 :547554.

Kleczkowski, M., Kluciński, W.Z., Jakubowski, T., Fabisiak1, M. and Dembele, K. 2008. Copper status and SOD activity in blood of cows affected with clinical mastitis. Bulletin of the Veterinary Institute in Pulawy 52:387-390.

Kommisrud, E., Østerås, O. and Vatn, T. 2005. Blood Selenium Associated with Health and Fertility in Norwegian Dairy Herds. Acta Veterinaria Scandinavica46:229240.
Machado, V. S., Bicalho, M. L. S., Pereira, R. V., Caixeta, L. S., Knauer, W. A., Oikonomou, G., Gilbert, R. O. and Bicalho, R. C. 2013. Effect of an injectable trace mineral supplement containing selenium, copper, zinc, and manganese on the health and production of lactating Holstein cows. Veterinary Journal197:451-456.

Sharma, A., Dhingra, P., Pander, B.L. and Kumar, R. 2006. Bovine subclinical mastitis: prevalence and treatment with homeopathic medicine. International Journal of Cow Science 2:1.

Sharma, N. 2008. Foot and mouth disease Mastitis cascade in dairy cattle: A field study. International Journal of Zoological Research 4(1):64-67.

Sharma, N., Gupta, S. K., Sharma, U. and Hussain, K. 2007. Treatment of clinical mastitis in buffalo-A case report. Buffalo Bulletin 26(2):56-58.

Sordillo, L. M. and Mavangira, V. 2014. The nexus between nutrient metabolism, oxidative stress and inflammation in transition cows. Animal Production Science 54 :1204-1214.

VanDen Broek, P. J. 1989. Antimicrobial drugs, microorganisms, and phagocytes. Review Infect. Dis. 11:213-245.

Weiss, W.P., Hogan, J.S. and Smith, K.L.1990. Relationships among selenium, vitamin Eand mammary gland health in commercial dairy herds. Journal of Dairy Science 73:381.

Yang, F. L.and Li, X. S. 2015.Role of antioxidant vitamins and trace elements in mastitis in dairy cows. Journal of Advanced Veterinary Animal Research2 (1): $1-9$.

\section{How to cite this article:}

Muhee A., H. U. Malik, I. Asharaf, O. S. Shah, A. Jan, Muheet, W. Rather and Showkeen Muzamil. 2017. Therapeutic Efficacies of Self-Formulated Anti-Oxidant Trace Minerals Formulation in Bovine Mastitis. Int.J.Curr.Microbiol.App.Sci. 6(7): 4595-4599. doi: https://doi.org/10.20546/ijcmas.2017.607.481 